\title{
Technological Culture in Professional Development: A Case Study between Brazil and Portugal
}

\author{
Rosa Branca Tracana ${ }^{1}$
}

Adão Cambraia ${ }^{2}$

\begin{abstract}
The aim of this work is answering to: what characteristics of space formation favour and limit Professional Development of Teacher, in a critical perspective, of Curricular Practice Recreation for transformation the interactive context? In Computing Course at IPFarroupilha (Santo Augusto) and in IPG Portugal was created a learning community for teachers on curricular recreation. We want to analyze the characteristics of the formative process experienced that provided professional development in the re-creation of the technological culture in education. It was developed an analysis of meetings, interviews with Brazilian and Portuguese students and teachers. For data analysis we use the discursive textual analysis, producing two interlinked categories: 1) re-creation of the technological culture in education; 2) professional development in the context under investigation. Each category was divided into subcategories. The categories allowed to understand and strengthen the view that the teachers are responsible for the formation of their peers and clarify characteristics that limit and/or promote the PDT in the re-creation of the technological culture education. Rebuilding the concept of technological culture is a movement of professional development required for the recognition that the school needs to open the doors to this knowledge.
\end{abstract}

Keywords: Professional development, teacher training, technologies

\section{INTRODUCTION}

This work is part of a larger search scope, whose thematic defines features of training space by providing professional development training in the re-creation of the curricular practice teaching in a graduate course. In Brazil, the research is developed in the context of the degree course in Computing (LC) - of the Federal Institute of Education, Science and Technology Farroupilha - campus Santo Augusto - Brazil (eight teachers) and for monitoring and analysis of space formation was organized a community of practice (CoP) named Teacher Professional Development in Degree in Computing DPDLiC to enhance interactive movements through cyberspace and meetings (Cambria \& Zanon, 2018). In the cited researchs, one can find characteristics of training space allowing the professional development.

In 2018, we cooperated with colleagues from Institute Politechnic of Guarda (IPG) - Portugal in order to organize a community of practice (similar to DPDLiC, regarding the use of hybrid spaces - cyberspace and in person; interaction of initial teacher training with basic education school) in order to understand if there is a professional teacher development in the Portuguese context. The goal is to present the characteristics of the Portuguese CoP. As it is not a question of transposing a formative process to

\footnotetext{
${ }^{1} \mathrm{PhD}$, Institute Polythecnic of Guarda - ESECD, rtracana@ipg.pt

2 Professor Doutor do Instituto Federal Farroupilha, adao.cambraia@iffarroupilha.edu.bt
} 
another location, we started by defining the subject pertaining to both courses and develop the proposed activities for the period of 30 days in the IPG. As the dialogue occurs between teacher's trainers of different courses, the thematic which enabled a dialogue is the presence and the development of a technological culture in teachers' training. From the Portuguese community, three teachers of the master trainers in Preschool Education and Teaching of the First Cycle of Basic Education, participated in conjunction with a researcher and a Brazilian scientific initiation scholarship, in order to characterize the different formative process pathways experienced. So the question was: which features are present in the community of practice in order to enhance the professional development of teacher trainer?

For the analysis of the presence and development of culture technology in teacher education it was used data produced by questionnaires, interviews, collective study meetings and experience reports. To understand the presence of the technological culture in Brazil we used teacher's publications (authors of the text) and students (another author of the text). In the Portuguese context, in addition to interviews, recorded meetings of study and reports of experience held at CoP (attended by three teachers) were used. The meetings and interviews were recorded and transcribed, and the dialogue in cyberspace facilitated the selection of excerpts for analysis, producing part of the research data. Instead of the names of the teachers it was used numbers $(1,2$ teacher, teacher, ...) to prevent identification and possible constraints. In the text, the excerpts will be identified with the country of origin of the member of the community. The construction process and the data analysis are based on Discursive Textual Analysis (Moraes \& Galiazzi, 2013), which allowed to identify relationships between conceptions of Teacher Professional Development (DPD) and the formative process, categorizing ideas around the recreation of curricular practice. The Discursive Textual Analysis can be understood as a self-organized process of building understanding in that new understandings emerge from a recursive sequence of three components the deconstruction of the texts of the corpus, the unitarization; the establishment of relationships between the unit elements, the categorization; the capture the emerging and the new understanding is communicated and validated (Moraes \& Galiazzi, 2013, p.12).

The new understanding that is communicated and validated is called metatext, where the written language plays two key roles: participation in the production of new understandings and of your communication become increasingly valid and consistent (Moraes \& Galiazzi, 2013, p.13). The text is divided into two parts, which are categories produced by data analysis. The first category is called Recreation of Technological Culture in Education and was divided into three subcategories: digital culture, digital world and computational thinking, which will be reviewed in topic 2 . In topic 3 , it was built the second category Teacher Professional Development in Context Investigated, which was divided into subcategories: relation between theory and practice and teacher training.

\section{Recreation of Technological Culture in Education}

The category Recreation of Technological Culture in Education is relevant for the two training courses. During the meetings of the $\mathrm{CoP}$ it was a theme present in studies of the trainers. So, we built a historical recurrence through reports made in the meetings with an informatic teacher of IPG about digital technologies in schools and build some alternatives (project planning system) for a collaborative work between the teacher training courses (Brazil and Portugal), in order to further dialogue with schools from both countries for the development of a technological culture in education. The category looks at the dialogue, in order to situate the reader regarding the similarities and differences between the teacher 
training courses, regarding the incorporation of technological culture in the curriculum of basic education. For text organization we will split this category into three subcategories, which are complementary and are interwoven. It was suggested the nomenclatures used in guidelines for computer education in basic education (SBC, 2016), which is divided into: Digital culture, Digital World and Computational Thinking. So, allowing the understanding of how the presence of each of these concepts in school and in teacher training occur, contributing, to achieving a technological culture in education, too.

The subcategory Digital Culture understands that communication can occur at any place and time. The internet, as well as smartphones, allows us to establish communication with other people in different points of the planet. We can choose the form of communication, whether through speech, writing or image. Change the forms of communication between people, which also shape and determine the culture (Castells, 2000, p. 354), making new forms of being, living and relating to each other and with the world. With regard to uses in everyday life, the subject of the research reported that: I use a lot of the technologies, in my daylife and in the course [teacher's training] to communicate or to carry out the work proposed by the teachers (student 5, Portugal) and student 3 complements: Daily I make use of technologies, because we live in a world where information is in the distance of a click. In the course it is essential to realize researchs and works/reports (Portugal). Both use technologies in their daylife and in the course of teacher education as a tool to aid in the construction of schoolwork, as they stand out mainly for research on the network. Digital culture in education comprises the: interdisciplinary relationships of computing with other fields of knowledge, seeking to promote the use of knowledge computational fluency for expression of solutions and cultural manifestations in a contextualized and criticism form (SBC, 2016, p.16).

In the context of teacher training in Portugal, as reported teachers and pupils of the course, the subcategory digital culture predominates, because, as teacher 1 (p. 22), the work of the semester of master's students is a page in wordpress and then become entangled with the kahoots in different areas (teacher 1, p.22, Portugal) what demonstrates a move to transform the classroom into a communicational space through digital technologies (Silva, 2001) and the links between different fields of knowledge. [...] the first tool we use is a tool widely used by everyone, that allows us to create collaborative environments and sharing. This is a blog for class and we all had access to this information. We put the students and the teacher as authors of the work, of course, but we ourselves blog. We think about everything in the creation of a learning environment. We had the help of the students of the master to help us in the contents. And what kind of content do we publish here? We publish comics using the Pixton. For students it is very motivating, it is a very simple tool in which the teacher and the student has complete freedom to create stories. In a very simple way students can expose how they see the world. To us how do we use it? To expose the problems, many times, students have difficulty understanding the mathematical problems proposed in a written way. In this way we represent graphically, through stories and use the content. In this case, it was in the area of adition, and was to calculate the area of a triangle. (Showing an example of a comic book). [...] In this case we have created several stories, several animations, which are dynamic and therefore solving mathematical problems is very simple, but we can think of activities for another areas (teacher 2, p.57-58, Portugal) On contrary in Brazil, as is a course related to the teaching of computing activities, are carried out that include digital culture, as for example, some works published by Brazilian students and teachers "The radio in school: union between free software and education" (Cambraia \& Talheimer, 2012); "The Classroom Flipped To Support The Teaching of a Foreign Language" (Rodrigues, Nascimento, \& Cambraia, 2017); "Learn and teach in Cyberculture: challenges and Innovative 
Perspectives" (Cambraia, 2018); "Accountability and Ethics in virtual: a proposal for a creative use of the network" (Moura \& Cambraia, 2017). These are publications that analyze the presence of knowledge of computing as a digital culture in education. The computer systems available to develop digital culture are presented on the internet in large numbers. There are a lot of Technologies. This link select a myriad of computational tools to search: https://drive.google.com/open?id=0ByF4Ir4 1uZqSTIOU0UxLXpYUVVZek9ZYnZOSDIVaTNEN213)

(teacher 3, p.42, Brazil). The differences between Portugal and Brazil is that in Brazil we have some banks of educational objects, which are animations and software, the RIVED, for example, which is developed by the people who do graduate studies in Educational Technologies. There's another that is the Latin American International Bank, where you find things in Portuguese, in Spanish, they are mainly animations in flash, most of them because the flash is still very present (student with fellowship 1, p.42, Brazil). This infinity of computer systems is also worked on basic education and master's degree in preschool and 1st CEB, as reporting: I'm going to support in development tools, which is also subdivided in several areas since documentation tools, presentation, animation, or video editing, so I put it there (pointing to the slides) several icons very known to all of us: YouTube is a great tool for us to use in the classroom; Pixtoon are mainly tools intended for the first cycle; Powton will do animation; Goanimator and AnimeMaker are for editing videos. Another type of tools that we can find and use in the classroom are: ScreenCapture and ScreenCast; for image editing - Pixlr; for graphics - Canvas; for forms we have Google Forms, Server Monkey. This part of the job, now referred, was part of the work that we have developed in the classroom with students of primary school (teacher 2, p.56-57, Portugal).

With the large amount of computational tools that exist it becomes difficult to know each one and relate them to the classroom activities. It requires a careful research, because it is not using the new technology, but use it by the need. We need to search which tools we can use in this or that context, based on the objectives of particular curricular component. Thus, the ICT can facilitate the curricular integration provided that it use is planned. If this occurs, then we have valuable tools that can support the implementation of projects that provide integration (student 1 , Brazil). The student makes a fundamental reference to the incorporation of technologies within the school, the role of the projects to relate the intradisciplinar with the world of life and the importance of planning, collaborative is the preference (Cambraia \& Zanon, 2018) as a way to incorporate the digital culture intentionally within the school. We have an experience related to other areas and a little bit of ICTs in special education and I think we're here to bring together various areas. We have areas like study of enviromnment, study of mathematics, we have the mother tongue both in Portuguese of Brazil and Portugal, we have several points in common, and we can say what types of materials that exist, what kinds of software, what types of connections can be used (teacher 1, p.21, Portugal)

The use of technologies in different contexts and situations makes it possible to understand that the teacher has what we call digital literacy. Digital literacy is required for teachers and students to move around in this sea of information and computational tools. We must teach literacy: teach how to find and how to use the information (teacher 2, p.56, Portugal) The General Direction of Portuguese Education in guidelines for the teaching of programming for primary school (first cycle) defines how: More than the ability to use computers, Digital Literacy encompasses a set of basic skills include the use and production of digital media, processing and retrieval of information, participation in social networks for knowledge creation and sharing, and a wide range of professional computer skills (Portugal - GGE, 2017, p.7). Digital literacy highlights the ways to read and write information, codes and verbal and non-verbal signals with use of computers 
and other digital devices, addressing the development of skills related to the use of equipment and its software with proficiency (Innovation Center for Brazilian Education - CIEB, 2018, p.18).

In subcategory Digital World is understandable that is formed by physical and virtual components, we need to understand that it is necessary to encode information and organize it so that it can be stored and retrieved as needed (SBC, 2016, p. 5). As the Center of Innovation for Brazilian Education - CIEB, who preferred to rename Digital World and Digital Culture for Digital Technology (based on national and international references), the main concepts of the axis are: data representation; hardware and software; networks. Under the Computing Course one of the projects developed in schools of basic education was the experience of a gymkhana, which resulted in a publication entitled: "Gymkhana in basic education: a proposal for the teaching of computation" (Winck, Riske, \& Cambraia, 2016). On the other side of the ocean, in Portugal, as a student of degree in Basic Education said: we had disciplines in our course as: educational technology (learn to handle several programs, such as powerpoint, excel) and technology in mathematics education, we learn programs that help to understand the mathematics in preschool and 1 st and 2 nd cycle of education, like the geogrebra, gcompris, among others (student 4, Portugal). In the subcategory digital world is also contemplated training for uses of software for teaching, that is, technological literacy, which is a fundamental aspect to enhance the production of knowledge in different fields. The first contact with technologies, such as computers, internet and software occurs in schools or at work when you have to teach and learn about computers. As we wish to use computers, we need a minimum of knowledge about them. We denominate this knowledge of technological literacy. For a technological literacy of the digital world it is necessary time to know the different computational systems and in which situation of studies are adequated, intensifying learning through cognitive tools (Jonassen, 2007).

The subcategory Computational Thinking contributes to focus on the power of analysis, decision, synthesis, organization and establishment of priorities, because it is not only the application developed with computers, but also a form of computational reasoning for the formulation and resolution of complex problems. It is not about transpose the knowledge of computer science into school knowledge, it involves contextualizing with the social, cultural, curricular and political aspects, providing new perspectives to understand and intervene in the world and transform reality. Computational thinking refers to the ability to systate, represent, analyze and solve problems. Despite being a recent term, it has been considered as one of the fundamental pillars of the human intellect, along with reading, writing and arithmetic, for as these, it serves to describe, explain and model the universe and its complex processes (SBC, 2016, p.3). According to Wing (2006), it develops the ability to think of multiple levels of abstraction. The author recognizes that the fundamental concepts of computing contribute to formulate and solve problems in different contexts of everyday life, being fundamental for all, not only for computer scientists. The main concepts of this axis are: abstraction, algorithms, decomposition and pattern recognition. Computational thinking is a way of interpreting the world, in which it combines critical thinking with fundamentals of computation. From the point of view of students' learning, the contribution of computational thinking and algorithms goes through elements such as i) be able to identify aspects of a problem that are likely to be implemented through computational means; ii) be able to assess the limitations and power of the computational tools they use; iii) be able to reuse, adapt and combine techniques and resolution strategies to new problems and iv) know how to recognize opportunities to use computational tools in new ways and with new objectives (Portugal, DGE, 2017, p.11). In Computing course, as already explained, it is a course of training of computer teachers, develops activities to potentialize computational thinking and logical reasoning in basic 
education, such as: "TEACHING PROGRAMMING: resignifying Paradigms in technological education" (Winck \& Cambraia, 2015). These are activities that permeate the disconnected computation to work in a playful way concepts of computational thinking to computer simulation and programming activities. The publications illustrate activities developed in basic education schools by the Computing course in the subcategory computational thinking.

In the category Recreation of the Technological Culture there was an "enlargement" of the understanding of the concept, which initially departed from the understanding that it was synonymous with digital culture (subcategory Digital Culture). After the collective study in the CoP enabled new understandings, approaching the digital world and computational thinking (subcategory Computational Thinking). This is a process of professional teacher development that is defended as paramount in the $\mathrm{CoP}$, which enables a permanent construction of teachers/trainers' learning.

\section{Professional Teacher Development in the Context Investigated}

The Professional Teacher Development category, in the investigated context, was produced with initial characteristics of the CoP to develop the professional teacher development. From this category, two subcategories were produced, Relationship between Theory and Practice and Teacher Training. They are categories that interconnect to provide the Recreation of the Technological Culture in Education. There is hardly a complexification of the concept of technological culture without a permanent tension between theory and practice.

The subcategory Theory and Practice Relationship is in the selected excerpts of the students belonging to the two courses. This category is highlighted, because most of the students emphasize the importance of the relationship between theory and practice (student 5, Portugal), it is evidence that the relationship between theory and practice isn't still seen as something that is indissociable in teacher education, needing to deepen these discussions in the collective. They still demonstrate that they are strongly linked to technical rationality when they say: the theory serves as the basis for practice and practice serves as a field to test the theory (student 1, Brazil) and the theory is essential to sustain practice (student 3, Portugal) These are statements arising from a division between theory and practice in which theory is seen as appropriation of an "applicable" knowledge in different situations and practice as a time to validate the studies carried out theoretically, that is, an inheritance of cartesian thought. According to Cambraia and Zanon (2018), this dichotomy in teacher education produces discompasses: a) between the pedagogical training and the contents that will teach and b) between theoretical knowledge and the world of professional practice. These discompasses cause damage to formation. According to teacher 4: Our students in Portugal seem to be formatted to think that what is important is practice and that this can be done without theoretical foundations (p. 88, Portugal) and it also points out that: as Leontiev stated, there is no better practice than a good theory (p.89). The teacher highlighted to the problem of falling into pure practicism and we find that our practice is the best and we follow an automated path without reflections and transformations in teaching. Thus, the physical approximation with the school space is seen as the only way to interact with the practice. Therefore, when questioning students about the interaction with the school, they usually refer sporadic moments, such as Internship, PeCC, Pibid, researches, visits and events (student 7, Brazil). It is necessary to be careful not to occur physical approximations of the school without interactions. The approximations mark situations in which the student goes to school and, hardly, produces critical reflections and collaborative planning. Collaborative planning provides 
interactions with the school and can be a way to provide professional teacher development (Cambraia \& Zanon, 2018).

The practical dimension should be understood as praxis, in which it reconstructs thoughts and pedagogical actions when experiencing reflexive processes on practices. It is a dialectical relationship between theory and practice, that is, the reflection on the practice and the development of collective studies enables a permanent tension between theory and practice, rebuilding them. In the discipline of Developmental Psychology, the theory and practice relationship occur: the student teacher is working with children with 7-year-olds, now let's see if the 7-year capacities will be the same in 3 years or if those were the ones they had years ago. Therefore, in this specific case of Developmental Psychology is easily perceived. I have a student and I can detect what are the characteristics of the thought that children of 7 years possess and did not have when they were 3. It is easier in this case of Psychology, but this implies also systematization of scientific knowledge (teacher 4, p.87, Portugal). Like the discipline of Developmental Psychology, the other teachers, of other disciplines, also need to think about the ways to relate theory and practice to produce meanings and meanings to socialized knowledge in the classroom. In one of the meetings, the graduate of the master's degree in preschool education and 1st CEB of the IPG, student @ 9, made an account of the work she developed in the internship on the use of technologies as a motivator for learning mathematics, in a class of 3 rd year of schooling (student @ 9, p. 51, Portugal). Teacher 1 complemented with a reflection on the theory and practice relationship in the development of digital culture. The Student 9 at the beginning of the master's course was working with mathematics and wondered to what extent these technologies may or may not provide learning in any other way. At an early stage we know that it is complicated the classroom environment nowadays with the teachers that we have in the active [teachers who do not experience digital culture] and that becomes complicated. We point out strategies to use the new technologies. We know that in a certain way we can get inside this classroom environment and in this specific issue of internship, we always have to deal with a certain care when we will address these concepts. We have to remember that we were with the teacher of the class and in this case we were lucky because she was extremely open to these situations. But in practice this does not happen, because one thing is theory and the other is practice. As student 9 said it is complicated to change this policy, which comes from a few years here, that in theoretical terms the technologies are great, but in practice no one knows how it happens (teacher 1, p.53, Portugal). The teacher draws attention to the necessary dialogue with the teacher of Basic Education to produce alternatives to incorporate digital culture into the classroom. The student developed a software, using Microsoft PowerPoint, titled "Who Wants to be a mathematician?" and found that students were more motivated to learn mathematics. This openness to dialogue, according to the teacher, usually does not occur, damaging the integration of technologies in education. The study of student 9 ends up showing that learning occurs in the digital culture. Then, the supervised Curricular Internship is a pathway, not the only one, to create a dialectical relationship between theory and practice, but the collaborative planning of Integrators Projects needs to be carried out in a collective way, creating means for dialogue between the subjects; follow-up and modifications of actions when necessary. Teacher training spaces should be prioritized by potentiating interactions between students, teacher trainers and teachers of basic education, breaking with the dichotomous view between initial and continuing education, because issues that need to be elucided, in the context of teacher education, are issues that are transversal to initial and continuing education, understood as a global process of permanent education (Canário, 1993, p.12), potentializing reflection on the practice to produce the curriculum (Sacristán, 2000). This can be one of the outputs to overcome the difficulty of incorporating the technological culture into Basic Education, as it is explained in the next category. 
In the subcategory Teacher Education we built a historical recurrence about the presence of the technological culture in the school through reports of Portuguese professors making relations with the evolution of this process in Brazil. Each teacher training course described in the preceding topic has a different specificity: a) degree in computer science-teacher training; b) master's degree in preschool education and teaching of the 1st CEB - equivalent to training in pedagogy in Brazil. The topic aims to analyze the presence of formation related to the incorporation of a technological culture in the school. Because of the massive presence of technologies in our lives and the growing awareness of teachers of the importance of curricular transformations through the technologies, this analysis makes a historical excerpt of the incorporation of technologies in the Portuguese and Brazilian context, based on reports from the teachers who participated in the $\mathrm{CoP}$ in Portugal giving a greater emphasis on the policies of teacher education undertaken so far, and, finally, we construct indications of the importance of the presence of a new professional in the school, promoting a recreation of the technological culture in the school. According to reports from Portuguese teachers, the work with the computation in the beginning of the decade of 90 was intensified with the Minerva project, which intended to train teachers in the use of ICT. It provided a set of contexts to the teachers. It had some success, but had no repercussions in the classroom, because there were no resources (teacher 2, p. 27, Portugal). It is a time when personal computers become more "popular", universities and schools organize computer labs and in the daily life of teachers the technologies become more present. But at this time the availability of computational resources is still scarce or at least the access of teachers is still difficult in order to integrate the technologies and build relationships with education. In these ongoing training projects, the basics were taught. We were training mainly in the use of tools that somehow improved their activity as a teacher. Never with a purpose, few times there were projects, but few were operationalized, had no participation on the part of teachers (teacher 2, p.27, Portugal). In the Brazilian school context it was not very different, what usually occurred was the creation of scenarios of uses: educational projects; video games; educational software and internet (Cambria, 2015) with a massive presence of tools such as text editors, slides, spreadsheets of calculus in an effort to build activities that potentialize the elaboration of knowledge. The difficulties of teacher education were similar to the Portuguese context. In some cases, the training was initiated with a significant number of teachers, which was not delayed to decrease. Implying the difficulty of the development of digital culture in school and, hardly, there were approximations to the digital world and computational thinking. At the end of the decade of 90 and beginning of 2000, the Portuguese Government proposed the Internet project at school. This was born from something that up to 97, 96 I was also very involved, which is what we call digital cities that is to promote the use of ICT in the context of society in general. At this point, what did we do? We installed computers with Internet in the municipality of Guarda. We had enough money to buy 10 computers and make ten connetions. It was crazy, because it was a war to decide which school would be contemed. The project took a long while to succeed and it was implemented at national level. All the schools received a computer. But sometimes we arrived at the schools and we noticed that the computer was like a beautiful mobile that which there (teacher 2, p.27, Portugal). In the decade of 1990 and, first years of 2000, the digital culture was potentialized and there were institutions that made a huge effort to receive a computer lab. In Brazil, computers were "popularized" through the National Educational Technology Program (PROINFO). In the decade of 1990, some schools started the implantation of computer labs. In 1997, the PROINFO (National Educational Technology Program) was launched, encompassing a set of actions aimed at promoting the pedagogical use of informatics in public basic education networks. PROINFO provided the expansion of equipment availability in public schools through computer labs and internet access. With the 
expansion of the presence of technological equipment in the school, increased the need for the school community to think about what to do with these equipments, how to integrate technologies in education and how to empower their teachers for an intentional use of Pedagogical Technologies (Zorzo, Nunes, Matos, Steinmacher, Leite, Araujo, ... Martins, 2017, p.82). In Portugal, according to the researcher teacher, about digital resources in education, a new stage began with the project Magalhães. The project envolved the distribution of small computers for students to use in the daily life. The computer Magalhães did not work, the schools were not prepared. My daughter switch on and she didn't want to work with it, because between the beginning and writing was half an hour (teacher 2, p.29-30, Portugal). The teacher highlights a technical difficulty, which possibly occurred in the Portuguese context, in which students had better computers at home and did not feel motivated to use the machine provided by the school and, on the other hand, the difficulty of teacher training - the schools were not prepared - means that teachers did not receive training to integrate technologies into education or if they received was not enough to innovate in the classroom. In Brazil, a project similar to Magalhães is the project One Computer per Student (UCA) which was implemented in the year 2007 and in 2010 was modified to program One Computer per Student (PROUCA), reaching 300 schools. Given the enormous territorial extension of the country, the PROUCA was far from reaching the totality of Brazilian schools and had undergone countless difficulties: From UCA to Prouca, the path of digital inclusion via school environment in Brazil was marked by economic conditionalities. These brands are reflected from the operational aspects of equipment acquisition till to the teacher training process, leaving a strong gap with regard to its pedagogical foundation (Echalar \& Peixoto, 2017, p.403). Lang (2016), highlights that in PROUCA, the use of technologies have not always been directed to modify learning experiences, being often used for the purpose of strengthening the traditional teaching process. Today the schools teach the same way 10 years ago, which is completely wrong. It is not only necessary to implement new features, but also take new methodologies to the classrooms. In short, it is necessary to reformulate the teaching (student 5, Portugal). The student makes it clear that the transformation of education through ICT is not perceptible. It ends up doing the same, with technologies, replaying old practices of decontextualized teaching and pure transmissionism. Coll (2008), in a reflection entitled Learn and Teach with ICT: expectations, realities and potentialities, highlights that there is a gap between expectations and what we do in education with technologies. But, he insists that we cannot abandon our expectations and proposes to consider technologies as psychological tools susceptible to mediate intra and inter-psicological processes (in the sense Vygostkiano) implicated in teaching and learning. Stressing that for technologies to fulfill this role, they need to mediate relations between the three elements of the interactive triangle (teachers, students and content). Making it clear that this is a typology of uses of technologies in formal education and does not represent in itself innovation perspectives and that is the whole of the curriculum which should be revised in order to adapt it to the formative needs and socio-cultural practices of the Information society (Coll, 2008, p. 125). The modification of this framework passes through the formation of teachers, because, often, teachers are isolated, suffer pressures in various ways and do not have time to deepen this knowledge [of technological culture], many have difficulty in using these tools (teacher 2, p. 56, Portugal), bringing evidence of the importance of teacher training for the development of technological culture in schools, that in the opinion of teacher 2 (p. 32): There is a person who has training in both things, [computation and education]. The aid in which the teacher refers is the realization of collective studies for the development of the technological culture, potentializing the digital world the computational thinking and development of integrative projects that provide the development of digital culture in the school space. In Brazil, since 1997 there have been a degree in 
computer science. The first degree in Compution course was created in 1997, at the University of Brasilia $(\mathrm{UnB})$. This was a specific course of graduation, focusing on Basic Education and with the prospect of breaking with training models " $3+1$ " based on technical rationality, for which it was believed that it was possible to form a teacher for Basic Education through pedagogical complementation (usually one year) at the end of The bachelor's (Zorzo et al., 2017, p.83). By making a quick survey on the internet about the existence of similar courses in Portugal we find 7 masters courses in computer teaching. In Portugal these courses are only offered by universities. In Brazil, the course is offered in universities and federal institutes, representing a total of 91 courses (SBC, 2015). This is a fundamental training for the integration of computer teaching in schools, because it is a teacher who articulates the different areas and proposes spaces for professional development by collective study and development of integrative projects creating a technological culture in the context of the school. It is not about someone who commands, but who communicates with the school community (Clastres, 1972). So, the articulation with other teacher training courses, for example, with the master's degree in preschool education and 1st CEB is a way to provide the technological culture in an interdisciplinary way in Basic Education, according to an integrative project with a thematic approach initiated during the Cooperative Research (November 2018). The construction of new curricular conceptions, provided by the study in CoP, we call it recreating the technological culture. In the category Recreation of the Technological Culture we developed an understanding of technological culture that encaged the concepts of digital culture, digital world and computational thinking, as concepts that complement each other.

The category Professional Development in the investigated context is related to the category Recreation of Technological Culture. It is a dialectical cycle of curricular recreation, that is, the more professional development of teachers, the more recreation of the technological culture and vice versa. Teaching professional development means providing that this process is permanent in teacher education.

\section{Final Considerations}

As a proposal for continuity of the CoP's interlocution, the joint creation (IF Brazil and IPG - ESECD Portugal) is planned to integrate projects with a thematic approach in Basic Education (4th of Elementary School), to be developed in schools in both countries. The projects are being conceived and, at the moment, it is a phase of production of didactic materials. In addition, the teachers were included in a virtual practice community Luso-Brazilian to discuss teacher training and continue the interactive process, constructing future research between IPG/Portugal and IF Brazil.

For the professional development of teachers with $\mathrm{CoP}$, there is not a single trajectory, which enabled in a context does not mean that it will enable another. The Portuguese CoP has some characteristics that have advanced the professional development of teachers. Among the characteristics, we highlight: 1) creation of the community of practice; 2) use of cyberspace and in-person meetings of sharing and discussion; 3) critical reflection on practice; 4) dialectical relationship between theory and practice; 5) collaborative planning of the Integrative project; 6) complexification of concepts by recreating the technological culture (digital culture, digital world and computational thinking); 7) teacher training. 


\section{REFERENCES}

Cambraia, A. (2015). A presença da cultura informática nas escolas. Publicatio UEPG: Ciências Sociais Aplicadas, 23, 71-89.

Cambraia, A. (2018). Aprender e ensinar na Cibercultura: Desafios e Perspectivas Inovadoras. Seminário de Inclusão Digital, Editora Universidade de Passo Fundo, 5, 1-10.

Cambraia, A., \& Zanon, L. B. (2018). Desenvolvimento profissional docente numa licenciatura: interlocuções sobre o projeto integrador. Revista Brasileira de Educação, 23, Rio de Janeiro.

Cambraia, A., \& Zanon, L. B. (2018). Desenvolvimento Profissional Docente na Recriação da Prática Curricular em Computação - por uma reforma do pensamento/ação. Revista de la Facultad de Ciencia y Tecnologia. Universidad Pedagógica Nacional, 2, 1-6.

Canario, R. (1993). Ensino Superior e Formação contínua de professores. Aprender - Revista da Escola Superior de Educação de Portalegre, 15.

Castells, M. (2000). A Sociedade em rede. São Paulo: Paz e Terra.

CIEB (2018). Currículo de Tecnologia e Computação, http://curriculo.cieb.net.br/curriculo, March.

Clastres, P. (1972). A sociedade contra o Estado - pesquisas de antropologia política. São Paulo: Cosac \& Naify.

Coll, C. (2008). Aprender y Ensinar con las TIC: expectativas, realidad y potencialidades. CARNEIRO, R.; TOSCANO, J. C.; DÍAZ, T. Los desafios de las TIC para el cambio educativo. Metas educativas 2021. Fundación Santillana. Organização dos estados Iberoamericanos para la Educación, la Ciencia y la Cultura (OEI), Madrid, Espanha.

Echalar, A. D. L., \& Peixoto, J. (2017). Programa Um Computador por Aluno: o acesso às tecnologias digitais como estratégia para a redução das desigualdades sociais. Revista Ensaio: Avaliação e Políticas Públicas em Educação, 25, 95.

Jonassen, D. H (2007). Computadores, Ferramentas Cognitivas: desenvolver o pensamento crítico nas escolas. Porto - Portugal: Porto Editora.

Lang, A. M. R. (2016). O Desenvolvimento Do Conhecimento Pedagógico Tecnológico Do Conteúdo De Professores Do Ensino Fundamental. Dissertação de mestrado pela Universidade Estadual Paulista. UNESP. Orientado por: Fernando Jaime González.

Moraes, R., \& Galiazzi, M. C. (2013). Análise Textual Discursiva, Ed. UNIJUÍ, $2^{\text {th }}$ edition.

Moura, S. P., \& Cambraia, A. (2017). Responsabilidade e ética no virtual: uma proposta de uso criativo da rede, http://www.mobrec.com.br/files/Anais\%20-\%20Mobrec\%20OFICIAL\%202017.pdf, March.

Portugal, D. G. E. (2017). Probótica - Programação e Robótica no Ensino Básico - Linhas Orientadoras, http://www.erte.dge.mec.pt/sites/default/files/probotica_-_linhas_orientadoras_2017.pdf, March.

Rodrigues, M. W., Nascimento, C. L., \& Cambraia, A. (2017). Sala de aula invertida como apoio para o ensino de lingua estrangeira, http://www.mobrec.com.br/files/Anais\%20\%20Mobrec\%20OFICIAL\%202017.pdf, March. 
Sacristán, G. (2000). O Currículo: uma reflexão sobre a prática. $3^{\text {th }}$ edition. Porto Alegre: Artmed.

SBC (2015). Educação Superior em Computação Estatísticas - 2014, http://www.sbc.org.br/documentos-dasbc/summary/133-estatisticas/1007-estatisticas-da-educacao-superior-2014, March.

SBC (2016). Diretrizes Curriculares Nacionais para os Cursos de Graduação em Computação, http://portal.mec.gov.br/index.php?option=com_docman\&view=download\&alias=11205pces136-11-pdf\&category_slug=julho-2012-pdf\&Itemid=30192, March.

Silva, M. (2001). Sala de Aula Interativa. $2^{\text {th }}$ edition. Rio de Janeiro: Quartet.

Talheimer, J., \& Cambraia, A. (2012). A mídia rádio na escola: uma união entre software livre e educação, http://gepid.upf.br/senid/2012/anais/96219.pdf, March.

Winck, J. A., \& Cambraia, A. (2015). Ensino de programação: Ressignificando paradigmas na educação tecnológica. XV Congresso Internacional de Educação Popular, Santa Maria, 1, 1-6.

Winck, J. A., Riske, M. A., \& Cambraia, A. (2016). Gincana na Educação Básica: uma proposta para o ensino da computação. Fernanda de Camargo Machado et al. (Org.). Desafios atuais na formação de professores: consolidando um espaço de estudos no IF Farroupilha. 1ed.São Leopoldo: Oikos, 1, 9099.

Wing, J. M. (2006). Computational thinking. In Commnications of the ACM, 33-35.

Zorzo, A. F., Nunes, D., Matos, E., Steinmacher, I.; Leite, J., Araujo, R. M., Correia, R., \& Martins, S. (2017). Referenciais de Formação para os Cursos de Graduação em Computação. Sociedade Brasileira de Computação (SBC). 153. ISBN 978-85-7669-424-3. 